\title{
EFEK ASAM HIALURONAT PADA BERBAGAI JENIS LUKA
}

\author{
Hidayatil Ardillah Saputri Amsia \\ Fakultas Kedoktern, Universitas Lampung, Jl. Prof. DR. Ir. Sumatri Brojonegoro No.1, Gedong Meneng, \\ Kec. Rajabasa, Kota Bandar Lampung, Lampung, Indonesia 35145 \\ hidayatilardila@gmail.com (+6289517429195)
}

\begin{abstract}
ABSTRAK
Penyembuhan luka adalah proses yang dinamis dan kompleks yang membutuhkan lingkungan yang sesuai untuk mendorong proses penyembuhan. Dengan kemajuan teknologi, berbagai produk telah dikembangkan untuk mengobati berbagai jenis luka dengan menargetkan berbagai aspek proses penyembuhan. Hyaluronan merupakan komponen kritis matriks ekstraseluler dengan beberapa peran berbeda. Meski strukturnya tergolong sederhana, hyaluronan memiliki banyak peran fisiologis., dan juga memainkan fungsi biologis penting yang berinteraksi dengan berbagai molekul dan reseptor. Tujuan dari literature review ini adalah untuk mengetahui dan meninjau manfaat asam hialuronat dalam penyembuhan berbagai jenis luka. Penelitian ini merupakan literature review yang melibatkan sebanyak 16 sumber pustaka dengan kata kunci yang digunakan yaitu 'hyaluronic acid dan wound' dengan tahun terbit antara 2011 - 2020. Abstrak dan full text jurnal dibaca dan dicermati, kemudian dilakukan analisis terhadap isi yang terdapat dalam tujuan penelitian dan hasil/temuan penelitian. Berbagai penelitian menunjukkan peran hyaluronan dalam beberapa proses biologis di berbagai jenis sel dan jaringan. Hyaluronan dalam sel epitel dapat menginduksi pensinyalan yang mempengaruhi sintesis protein spesifik yang terlibat tidak hanya dalam pengendalian pertumbuhan bakteri tetapi juga dalam regenerasi dan perbaikan jaringan.
\end{abstract}

Kata kunci: asam hialuronat; penyembuhan luka

\section{EFFECTS OF HYALURONIC ACID ON VARIOUS TYPES OF WOUNDS}

\begin{abstract}
Wound healing is a dynamic and complex process that requires an appropriate environment to promote the healing process. With advances in technology, various products have been developed to treat different types of wounds by targeting different aspects of the healing process. Hyaluronan is a critical component of the extracellular matrix with several different roles. Despite their relatively simple structure, hyaluronan has many physiological roles, and also plays important biological functions interacting with various molecules and receptors. The purpose of this literature review is to determine and review the benefits of hyaluronic acid in healing various types of wounds. This study is a literature review involving 16 literature sources with the keywords used, namely 'hyaluronic acid and wound' with the publication year between 2011 - 2020. Abstracts and full text journals are read and examined, then an analysis of the content contained in the research objectives is carried out and research results/findings. Various studies have shown the role of hyaluronan in several biological processes in various types of cells and tissues. Hyaluronants in epithelial cells can induce signaling that affects the synthesis of specific proteins which are involved not only in controlling bacterial growth but also in tissue regeneration and repair.
\end{abstract}

Keywords: hyaluronic acid; wound healing 


\section{PENDAHULUAN}

Luka didefinisikan sebagai gangguan pada kontinuitas lapisan epitel kulit atau mukosa akibat kerusakan fisik maupun termal. Berdasarkan durasi dan sifat proses penyembuhan, luka dapat dikategorikan sebagai luka akut dan kronis. Luka akut adalah luka pada kulit yang terjadi secara tiba-tiba akibat kecelakaan atau cedera bedah, dapat sembuh pada kerangka waktu yang dapat diprediksi dan diharapkan biasanya dalam 8-12 minggu tergantung pada ukuran, kedalaman dan tingkat kerusakan pada lapisan epidermis dan dermis kulit. Sementara itul luka kronis di sisi lain gagal berkembang melalui tahap penyembuhan normal dan tidak dapat diperbaiki secara tertib dan tepat waktu. Luka kronis umumnya terjadi akibat ulkus dekubitis, ulkus tungkai, dan luka bakar. Penyembuhan luka adalah proses regenerasi dan pertumbuhan jaringan yang dinamis dan kompleks melalui empat fase yang berbeda yaitu fase koagulasi dan hemostasis (segera setelah cedera); fase inflamasi, (segera setelah cedera pada jaringan) dimana terjadi pembengkakan; periode proliferasi, di mana jaringan dan pembuluh darah baru terbentuk dan fase pematangan, di mana renovasi jaringan baru terjadi. Fase-fase ini terjadi secara teratur yang tumpang tindih satu sama lain dalam kaskade yang terhubung dengan baik (Dhivya et al., 2015).

Dengan sepertiga dari populasi orang dewasa yang saat ini hidup dengan diabetes dan 6,5 juta kasus ulkus kulit kronis setiap tahun, investigasi ke dalam proses yang terlibat dalam penyembuhan luka mengambil peran yang lebih penting dalam beberapa tahun terakhir. Adanya peningkatan kejadian diabetes dan obesitas di seluruh dunia, maka beban finansial untuk mengobati luka kronis juga meningkat. Diperkirakan lebih dari 25 miliar USD dihabiskan setiap tahun untuk pengobatan luka kronis saja. Biayanya bahkan lebih mengejutkan ketika salah satu faktor dalam hilangnya produktivitas untuk individu yang terkena dampak serta fasilitas jangka panjang (Dreifke et al., 2015).

Perawatan pada luka melibatkan penggunaan penutup, adanya metode lanjutan yang menggunakan produk yang secara ideal diperoleh dari komponen biologis yang ditangani secara minimal, tidak beracun, hipoalergenik dan memungkinkan pengangkatan produk tanpa kerusakan jaringan lebih lanjut. Selain itu, penutup luka harus menyediakan lingkungan yang lembab, mendorong pertukaran gas, mencegah perkembangan bakteri, mengontrol eksudat yang berlebihan, dan mempertahankan suhu lokal yang konstan tanpa perlu perubahan rutin. Dalam konteks ini, asam hialuronat menonjol sebagai teknologi baru untuk mengobati luka kulit dan epidermal. Zat ini terdiri dari bahan biologis yang berasal dari komponen yang diekstraksi dari matriks ekstraseluler (Longinotti, 2014).

Asam hialuronat memiliki fitur penting untuk cakupan biologis seperti biokompatibilitas dan biodegradabilitas, ditambah lagi tidak menyebabkan imunogenisitas. Sebagai agen terapeutik, asam hialuronat digunakan dalam berbagai aplikasi, di antaranya operasi mata, rekonstruksi jaringan,penyakit sendi degeneratif dan inflamasi, penggantian cairan sinovial, pelepasan zat kimia dalam implan bedah, sistem enkapsulasi dan pelepasan terkontrol. obat dan kosmetik topical. Dalam pengobatan luka lokal, digunakan dalam bentuk krim, gel, atau 
kain kasa yang diresapi untuk mempercepat penyembuhan (Dalmedico et al., 2016). Asam hialuronat (HA) adalah polisakarida yang termasuk dalam keluarga glikosaminoglikan dan terdiri dari unit dasar dua gula, asam glukuronat dan N-asetil-glukosamin. Asam hialuronat biasanya terdapat sebagai massa molekul tinggi dalam cairan sinovial yang mengelilingi sendi, tulang rawan, dan jaringan mata dan kulit. (Neuman et al., 2015).

Asam hialuronat merupakan komponen utama dari matriks ekstraseluler. Penyerapan kelembapan dan sifat viskoelastiknya memainkan peran penting dalam proses penyembuhan luka, melalui interaksi kompleks dengan sel dan komponen ekstraseluler lainnya. Asam hialuronat diketahui secara aktif terlibat dalam semua tahap penyembuhan luka, dari promosi peradangan dini dan pembentukan jaringan granulasi, melalui fasilitasi migrasi sel ke dalam matriks luka, ke epitelisasi ulang, melalui fungsi pembersihan radikal bebasnya, dan peran dalam proliferasi dan migrasi keratinosit. (Dereure et al., 2012). Oleh karena itu, tujuan dari literature review ini adalah untuk mengetahui dan meninjau manfaat asam hialuronat dalam penyembuhan berbagai jenis luka, sehingga dapat memberikan informasi baru dan bermanfaat bagi masyarakat.

\section{METODE}

Penelitian ini merupakan studi literature review, yang menyajikan kembali materi yang diterbitkan sebelumnya, dan melaporkan fakta atau analisis baru. Penelusuran sumber pustaka dalam artikel ini melalui database PubMed dan Google Scholar. Sumber pustaka yang digunakan dalam penyusunan melibatkan 16 pustaka dengan kata kunci yang digunakan dalam penelusuran antara lain 'hyaluronic acid dan wound' dengan tahun terbit antara 2011-2020. Pemilihan artikel sumber pustaka dilakukan dengan melakukan peninjauan pada judul, abstrak dan hasil yang membahas manfaat asam hialuronat terhadap penyembuhan luka. Abstrak dan full text jurnal dibaca dan dicermati, kemudian dilakukan analisis terhadap isi yang terdapat dalam tujuan penelitian dan hasil/temuan penelitian. Dilakukan koding terhadap isi jurnal yang direview berdasarkan garis besar atau inti dari penelitian tersebut yang dilakukan dengan mengurai dalam sebuah kalimat, dan jika sudah terkumpul kemudian dicari persamaan dan perbedaan pada masing-masing penelitian lalu dibahas untuk menarik kesimpulan.

\section{HASIL}

Schneider \& Landsman (2019) melakukan studi kasus dari data yang dikumpulkan dari 6 pasien dengan ulkus kaki diabetik dan 3 pasien dengan ulkus kaki vena, yang diberikan matriks asam hialuronat yang diesterifikasi (Hyalomatrix). Hasilnya didapatkan rata-rata waktu evaluasi adalah 55,25 hari ( $\mathrm{SD}=2,76$ hari). Selama periode ini, rata-rata perubahan ukuran luka berkurang sebesar $6,43 \mathrm{~cm}^{2}(\mathrm{SD}=7,55$ $\left.\mathrm{cm}^{2}\right)$, dari $7,93 \mathrm{~cm}^{2}\left(\mathrm{SD}=8,12 \mathrm{~cm}^{2}\right)$ menjadi $1,50 \mathrm{~cm}^{2}\left(\mathrm{SD}=0,92 \mathrm{~cm}^{2}\right)$, dan didapatkan peningkatan sebesar 74,38\% $(\mathrm{SD}=32,01 \%)$ jaringan granulasi dari sebelumnya $46,11 \%$ (SD $=22,05 \%)$, yang menunjukkan sekitar 50\% peningkatan jaringan granulasi selama 55 hari evaluasi. Disimpulkan bahwa asam hialuronat adalah komponen penting dalam rangkaian kompleks penyembuhan luka dan kemungkinan besar bertanggung jawab untuk perbaikan klinis pada luka dalam seri 
kasus yang disajikan (Schneider \& Landsman, 2019).

Penelitian lain oleh Yildırım et al. (2017), 36 pasien yang membutuhkan free gingival graft (FGG) secara acak dibagi menjadi tiga kelompok dalam uji klinis terkontrol secara acak. Gel asam hialuronat $0,2 \%$ dan $0,8 \%$ digunakan pada kelompok uji 1 dan 2 yang dilindungi dengan dressing periodontal, sedangkan luka hanya ditutup dengan dressing periodontal pada kelompok kontrol. Pada hari ke 3,7,14 dan 21, nyeri dan sensasi terbakar dicatat dengan menggunakan visual analog scale (VAS) serta parameter lain seperti complete epithelization (CE) dan color match pada hari 3,7,14,21,42. Hasilnya didapatkan kelompok uji mengalami nyeri yang lebih sedikit dibandingkan dengan kelompok kontrol pada hari ke3 ( $\mathrm{p}<0,001)$ dan hari ke-7 ( $\mathrm{p}<0,001)$. Rerata skor VAS untuk sensasi terbakar lebih tinggi pada kelompok kontrol pada hari ke-3 dibandingkan dengan kelompok uji $1(\mathrm{p}=0,033)$ dan $2(\mathrm{p}=$ $0,020)$. CE pada semua pasien di kedua kelompok uji dicapai pada hari ke 21, sementara itu dicapai pada hari ke 42 pada kelompok kontrol. Kelompok uji menunjukkan skor kecocokan warna yang lebih tinggi daripada kelompok kontrol pada hari ke 21 (masing-masing $\mathrm{p}<0,001$ dan $\mathrm{P}<0,001)$ dan hari ke 42 (masing-masing $\mathrm{p}=0,004$ dan $\mathrm{p}=$ 0,002) (Yıldırım et al., 2017).

Penyembuhan ulkus kaki diabetik yang cepat dan lengkap merupakan sebuah tantangan karena lingkungan penyembuhan luka yang tidak bersahabat dari pasien diabetes. Beberapa pendekatan perawatan multimodal, bahan pembalut canggih yang menggunakan asam hialuronat (HA) telah terbukti efektif, namun penelitian sebelumnya menggunakan asam hialuronat dengan zat biologis tambahan, sehingga mengganggu dalam menentukan efek klinis asam hialuronat yang sebenarnya pada ulkus kaki diabetik. Lee et al (2016) melakukan penelitian dengan menggunakan pembalut asam hialuronat tanpa zat tambahan apapun, dengan membagi kelompok menjadi kelompok uji (bahan pembalut asam hialuronat), dan kelompok kontrol (bahan pembalut konvensional). Pada akhir penelitian, kelompok uji $[84,6 \%$ (11/13)], menunjukkan tingkat kesembuhan total yang lebih tinggi secara signifikan dibandingkan dengan kelompok kontrol [41,6\% (5/12)], dengan nilai $p=0,041$. Selain itu, kecepatan penyembuhan ulkus yang lebih cepat $(\mathrm{p}=0,022)$ dan durasi rata-rata yang lebih pendek untuk mencapai pengurangan ukuran ulkus $50 \%$ diamati pada kelompok uji $(\mathrm{p}=0,004)$. Waktu untuk $50 \%$ tingkat penyembuhan ulkus juga menunjukkan durasi yang lebih singkat secara signifikan pada kelompok studi (21 hari vs 39 hari, $p=0,0127$ ). Tidak ditemukan efek samping yang terkait dengan bahan pembalut yang digunakan dalam penelitian. Sebagai komponen utama dari matriks ekstraseluler, penelitian ini mendukung keamanan dan kemanjuran balutan asam hialuronat murni tanpa zat tambahan dalam menangani ulkus kaki diabetik (Lee et al., 2016).

Penelitian lain juga dilakukan oleh Marin et al (2020) yang melibatkan 30 pasien dengan diabetes tipe 2 yang tidak terkontrol dengan baik, yang membutuhkan pencabutan dua gigi anterior bilateral yang sama di rahang bawah mulut. Soket yang diberi asam hialuronat $0,8 \%$ mewakili kelompok studi, sedangkan soket yang tidak menggunakan asam hialuronat mewakili kelompok kontrol. Tingkat penutupan luka (wound closure rate/ WCR), skor 
klinis dalam skala penyembuhan luka (wound healing scalel WHS) dan intensitas nyeri dalam Visual Analog Scale (VAS) dicatat. Hasil penelitian menunjukkan WCR yang lebih tinggi di lokasi ekstraksi di mana asam hialuronat diterapkan dan didapatkan perbedaan yang signifikan secara statistik ( $\mathrm{p}<0,001)$. Berkenaan dengan WHS, soket yang dirawat dengan asam hialuronat menunjukkan penyembuhan yang lebih baik, terutama pada hari ke $10(\mathrm{p}=0,006)$ dan hari ke $15(\mathrm{p}=$ 0,021). Namun, tidak ada perbedaan yang signifikan secara statistik pada skor VAS antar kelompok. Sehingga dalam penelitian tersebut simpulkan bahwa asam hialuronat yang diberikan pasca ekstraksi pada pasien dengan diabetes yang tidak terkontrol dapat meningkatkan penyembuhan luka, terutama pada hari-hari pertama setelah aplikasi (Marin et al., 2020).

\section{PEMBAHASAN}

Terdapat dua jenis utama luka yaitu luka kronis dan akut. Luka akut biasanya bersifat superfisial melibatkan baik epidermis dan dermis superfisial. Contoh luka akut adalah sayatan bedah, luka termal, lecet, dan laserasi dengan komplikasi utama yang terkait dengan infeksi. Penyembuhan luka akut diatur oleh sitokin dan faktor pertumbuhan yang dilepaskan di bagian proksimal luka. Fase inflamasi yang terkait dengan penyembuhan luka melibatkan migrasi neutrofil, makrofag, dan limfosit ke luka yang menghasilkan gejala inflamasi yang berlangsung selama kurang lebih 2 minggu. Seperti yang dinyatakan sebelumnya, penyembuhan luka melibatkan beberapa tahap dan pada titik mana pun prosesnya bisa terhenti yang menyebabkan potensi disfungsi. Jika peradangan berlanjut selama berbulan-bulan atau bertahuntahun luka dapat diklasifikasikan menjadi luka kronis dan dapat dikaitkan dengan berbagai perubahan patologis termasuk peningkatan aktivitas protease dan infeksi. Fase proliferasi mengikuti fase inflamasi, dan ditandai dengan pembentukan jaringan baru, granulasi dan pembentukan jaringan epitel (reepitelisasi) dan memulihkan jaringan vaskular. Keratinosit melibatkan perbaikan penghalang epidermis sementara fibroblas dan sel endotel bertanggung jawab untuk angiogenesis dan produksi matriks ekstraseluler. Fase renovasi melibatkan reorganisasi dan kontraksi matriks yang baru terbentuk dan dapat berlangsung selama beberapa tahun. Umumnya, luka akut cenderung sembuh dalam 3 minggu sedangkan luka kronis cenderung bertahan minimal 3 bulan sejak masa cedera (Dreifke et al., 2015).

Luka kronis dapat terjadi dengan adanya kerusakan semua lapisan kulit termasuk epidermis, dermis, dan jaringan lemak subkutan yang mendasarinya. Luka kronis biasanya diakibatkan sebagai komplikasi dari proses penyakit lain, misalnya ulkus kaki akibat diabetes, ulkus tekanan akibat cedera tulang belakang, dan bahkan sebagai hasil dari proses neurodegeneratif seperti penyakit Pick (Dreifke et al., 2015). Banyak masalah yang berkaitan dengan penyembuhan luka kronis yang berfokus pada efek merusak yang dimiliki berbagai proses pada mekanisme pensinyalan biokimia, deposisi matriks ekstraseluler, dan migrasi sel. Sebagai contoh, hiperglikemia pada penderita diabetes diyakini dapat menghambat pembentukan matriks ekstraseluler dengan meningkatkan regulasi metaloproteinase matriks melalui peningkatan level tumor necrosis factoralpha (TNF- $\alpha$ ) dan interleukin (IL-1 $\beta$ ). Selain disfungsi matriks ekstraseluler, 
ulkus kaki diabetik (DFU) diamati telah mengganggu migrasi keratinosit dan fungsi leukosit yang menyebabkan infeksi. Selain itu, tingkat deplesi fosfat anorganik dalam ulkus diabetes juga menyebabkan rendahnya tingkat adenosin trifosfat (ATP), menyebabkan kemunduran yang signifikan pada respon imun (Lev-Tov et al., 2013). Molekul pensinyalan seperti faktor pertumbuhan epidermal (EGF) berfungsi secara normal untuk merangsang proliferasi dan migrasi keratinosit selama penutupan luka, namun, penuaan, penyakit, dan kerusakan akibat sinar matahari menghambat kemampuan keratinosit untuk merespon EGF dan mitogen pemicu pertumbuhan lainnya. Mekanisme tersebut berkontribusi pada gangguan penyembuhan luka dan merupakan fokus dari modalitas terapeutik baru yang berpusat pada penggabungan ekstraseluler dan berbagai molekul pensinyalan dalam luka kronis untuk mendorong regenerasi dan perbaikan (Dreifke et al., 2015). Sementara itu, standar perawatan luka kronis saat ini terdiri dari prosedur swab untuk infeksi, pembersihan, pembalutan, dan dalam beberapa kasus debridemen luka (Margolis et al., 2011). Untuk ulkus diabetes, kontrol glukosa sistemik, debridemen jaringan nonviable, dan pemeliharaan perfusi ekstremitas yang adekuat adalah yang terpenting (Dreifke et al., 2015).

Asam hialuronat (HA) adalah anggota keluarga besar glikosaminoglikan (GAG), dan merupakan komponen utama matriks ekstraseluler. Fitur unik yang membedakan asam hialuronat dari GAG lainnya adalah strukturnya yang sederhana dan ukuran molekulnya yang besar. Molekul asam hialuronat terdiri dari asam D-glukuronat dan N-asetil-Dglukosamin yang terikat dengan hubungan $\beta$-glikosidik. Satuan molekul sederhana ini berulang ribuan kali membentuk struktur polimer linier yang sangat panjang, dengan berat molekul mencapai 5 x 106 kDa (Vigetti et al., 2014).

Asam hialuronat disintesis oleh sintase HA pada permukaan bagian dalam membran sel dan ditranslokasi ke ruang ekstraseluler bersama dengan perpanjangan rantai polimer. Ini adalah metode sintesis yang unik, berbeda dari GAG lain yang disintesis di ruang intraseluler. Asam hialuronat juga satusatunya GAG yang tidak terkait dengan protein inti, dan tidak mengalami modifikasi pasca sintetik. Polimer hyaluronan panjang memiliki kemampuan mengikat air dalam jumlah besar. Sifat higroskopis dan viskoelastik asam hialuronat menjadikannya komponen sempurna dari cairan vitreous, cairan sendi, dan derma. Hyaluronan dalam bentuk aslinya dari polimer yang sangat panjang dikenal sebagai hyaluronan dengan berat molekul tinggi (high molecular weight/HMW). Namun, dalam kondisi tertentu, dapat diuraikan menjadi fragmen kecil yang disebut sebagai HA berat molekul rendah (low molecular weight HA /LMWHA) (Aya \& Stern, 2014).

Pergantian Hyaluronan adalah proses yang cepat, karena waktu paruh molekul HA dalam aliran darah hanya sekitar 25 menit. Fragmentasi hyaluronan dikendalikan oleh enzim yang disebut hyaluronidases. Hyaluronidase-1 (Hyal1) dan hyaluronidase-2 (Hyal-2) bertanggung jawab atas degradasi HA di jaringan somatik. Pada Hyal-2 pertama yang merupakan enzim yang berhubungan dengan membran sel mendegradasi hyaluronan menjadi fragmen dengan berat molekul 
mencapai $20 \mathrm{kDa}$. Molekul HA ini kemudian diendositosis dan dikirim ke lisosom, di mana pencernaan lebih lanjut dilakukan oleh Hyal-1. Dalam jaringan yang terluka, radikal bebas juga mampu menguraikan polimer HA menjadi fragmen yang lebih kecil (Litwiniuk et al., 2016).

Penyembuhan luka adalah proses biologis yang kompleks, terdiri dari serangkaian kejadian berurutan yang bertujuan untuk memperbaiki jaringan yang terluka. Komponen matriks ekstraseluler memainkan peran penting dalam regulasi semua fase perbaikan jaringan, termasuk migrasi sel, inflamasi, angiogenesis, remodeling, dan pembentukan jaringan parut. Penelitian telah mengungkapkan bahwa asam hialuronat tidak hanya menyediakan lingkungan mikro luka, tetapi juga terlibat dalam berbagai jalur pensinyalan yang diaktifkan di dasar luka selama proses penyembuhan. Asam hialuronat yang merupakan komponen matriks ekstraseluler dasar dengan beberapa sifat unik yang menjadikannya pemain kunci dalam regenerasi jaringan (Litwiniuk et al., 2016).

Asam hialuronat memainkan peran yang beragam di semua tahap penyembuhan luka. Asam hialuronat meningkatkan sintesis jaringan pada fase inflamasi awal perbaikan luka. Asam hialuronat meningkatkan infiltrasi sel dan membantu dalam mobilisasi sitokin proinflamasi penting seperti TNF- $\alpha$ dan interleukin 8. Pada tahap awal, jaringan granulasi didominasi oleh matriks ekstraseluler kaya asam hialuronat. Selama pembentukan jaringan granulasi ini,asam hialuronat yang diproduksi secara lokal memfasilitasi proliferasi dan migrasi sel ke matriks luka sementara. Asam hialuronat juga memainkan peran utama dalam organisasi matriks jaringan granulasi melalui receptor for HA-mediated motility (RHAMM). Di fase selanjutnya terjadi stabilisasi matriks jaringan granulasi. Asam hialuronat menstabilkan matriks dengan membersihkan radikal bebas dengan sitokin proinflamasi, yang mencegah kerusakan dari matriks ekstraseluler. Akhirnya, di tahap proliferasi penyembuhan luka, asam hialuronat menopang keratinosit basal yang keduanya berkaitan dengan dukungan dan regulasi seluler (Schneider \& Landsman, 2019).

Asam hialuronat juga merupakan polisakarida yang terdapat secara alami dalam tubuh manusia di seluruh jaringan ikat, epitel, dan saraf. Asam hialuronat menyediakan dua fungsi yang sangat penting dalam penyembuhan luka sebagai bagian dari proliferasi dan migrasi sel. Pertama, menyediakan struktur sementara pada tahap awal luka. Struktur ini membantu memfasilitasi difusi suplai nutrisi dan membantu membersihkan luka dari produk limbah dari metabolisme sel. Kedua, dan yang paling penting, asam hialuronat terlibat erat dalam proliferasi dan migrasi keratinosit (jenis sel epidermis atau lapisan terluar kulit). Akhirnya, struktur sementara ini diganti saat luka 'matang', dengan penambahan molekul protein proteoglikan (yang berfungsi untuk memberikan tekanan hidrasi dan pembengkakan ke jaringan sehingga memungkinkan untuk menahan gaya kompresi) dan kolagen. Lebih lanjut, karena asam hialuronat adalah makromolekul higroskopis, ia sangat osmotik, memungkinkan untuk mengontrol hidrasi selama periode perbaikan luka dan proses peradangan yang terkait dengannya (ketika tingkat asam hialuronat meningkat). Adanya 
peningkatan kadar asam hialuronat selama proses ini juga sangat relevan dengan proliferasi dan migrasi sel. Sebagian karena keberadaan asam hialuronat, penjangkaran sel ke matriks ekstraseluler melemah, memungkinkan pelepasan dan memfasilitasi migrasi dan pembelahan sel. Saat jaringan granulasi matang, asam hialuronat terdegradasi, dan saat level turun, lebih banyak molekul protein diproduksi. Protein mengikat asam hialuronat menjadi proteoglikan dan melanjutkan proses penyembuhan untuk membangun ketahanan jaringan. Molekul asam hialuronat mampu menyerap hingga 3.000 kali beratnya sendiri dalam air. Oleh karena itu asam hialuronat juga memiliki peran penting sebagai agen hidrasi untuk jaringan seperti yang disebutkan sebelumnya (Voigt \& Driver, 2012).

Angiogenesis diketahui merupakan bagian penting dari fase proliferasi dari proses penyembuhan luka. Selama fase ini, sel endotel bermigrasi dari pembuluh ke jaringan sekitarnya di mana mereka berkembang biak dan membuat perlekatan sel-ke-sel baru serta struktur tubulus kapiler baru. Interaksi antara komponen sel endotel dan matriks ekstraseluler sangat penting dalam regulasi formasi pembuluh baru. Sejumlah penelitian telah menunjukkan bahwa pensinyalan asam hialuronat memainkan peran penting dalam regulasi angiogenesis, terutama dengan mempengaruhi perilaku sel endotel. Baik HMWHA dan LMWHA adalah regulator angiogenesis yang kuat, namun keduanya menunjukkan efek berlawanan pada proliferasi dan motilitas sel endotel. Terbukti bahwa LMWHA merangsang proliferasi sel endotel vaskular, migrasi, dan pembentukan tubulus secara in vitro, serta dalam berbagai model angiogenesis in vivo. Pada saat yang sama HMWHA menampilkan sifat antiangiogenik dengan menghambat proliferasi sel endotel, motilitas, dan pembentukan tunas (Litwiniuk et al., 2016).

\section{SIMPULAN}

Asam hialuronat selain berperan penting sebagai komponen struktural matriks ekstraseluler, juga memiliki peran penting dalam metabolisme jaringan dan memainkan peran yang beragam di semua tahap penyembuhan luka. Hyaluronan dalam sel epitel dapat menginduksi pensinyalan yang mempengaruhi sintesis protein spesifik yang terlibat tidak hanya dalam pengendalian pertumbuhan bakteri tetapi juga dalam regenerasi dan perbaikan jaringan. Sehingga, studi tentang pensinyalan hyaluronan dan metabolisme hyaluronan dapat menjadi strategi inovatif dalam perbaikan jaringan dan pengendalian peradangan.

\section{DAFTAR PUSTAKA}

Aya, K. L., \& Stern, R. (2014). Hyaluronan in wound healing: Rediscovering a major player. Wound Repair and Regeneration, 22(5), 579-593. https://doi.org/10.1111/wrr.12214

Dalmedico, M. M., Meier, M. J., Felix, J. V. C., Pott, F. S., Petz, F. de F. C., \& Santos, M. C. (2016). Hyaluronic acid covers in burn treatment; a systematic review. Journal of School of Nursing, 50(3), 519-524.

Dereure, O., Czubek, M., \& Combemale, P. (2012). Efficacy and safety of hyaluronic acid in treatment of leg ulcers: A doubleblind RCT. Journal of Wound Care, 21(3), 131-139. https://doi.org/10.12968/jowc.201 


\subsubsection{1}

Dhivya, S., Padma, V. V., \& Santhini, E. (2015). Wound dressings - A review.

BioMedicine

(Netherlands), 5(4), 24-28. https://doi.org/10.7603/s40681015-0022-9

Dreifke, M. B., Jayasuriya, A. A., \& Jayasuriya, A. C. (2015). Current wound healing procedures and potential care. Materials Science and Engineering $C$, 48, 651-662. https://doi.org/10.1016/j.msec.201 4.12.068

Lee, M., Han, S. H., Choi, W. J., Chung, K. H., \& Lee, J. W. (2016). Hyaluronic acid dressing (Healoderm) in the treatment of diabetic foot ulcer: A prospective, randomized, placebo-controlled, single-center study. Wound Repair and Regeneration, 24(3), 581-588.

https://doi.org/10.1111/wrr.12428

Lev-Tov, H., Li, C. S., Dahle, S., \& Isseroff, R. R. (2013). Cellular versus acellular matrix devices in treatment of diabetic foot ulcers: study protocol for a comparative efficacy randomized controlled trial. Trials, 14(8), 1-8. https://doi.org/10.1002/term.2884

Litwiniuk, M., Krejner, A., \& Grzela, T. (2016). Hyaluronic Acid in Inflammation and Tissue Regeneration. Sys, 28(3), 78-88. http://dx.doi.org/10.1016/j.system. 2012.10.017

Longinotti, C. (2014). The use of hyaluronic acid based dressings to treat burns: A review. Burns \& Trauma, 2(4), 162. https://doi.org/10.4103/23213868.142398
Margolis, D. J., Hoffstad, O., Nafash, J., Leonard, C. E., Freeman, C. P., Hennessy, S., \& Wiebe, D. J. (2011). Location, location, location: Geographic clustering of lower-extremity amputation among medicare beneficiaries with diabetes. Diabetes Care, 34(11), 2363-2367. https://doi.org/10.2337/dc11-0807

Marin, S., Popović-Pejičić, S., Radošević-Carić, B., Trtić, N., Tatić, Z., \& Selaković, S. (2020). Hyaluronic acid treatment outcome on the post-extraction wound healing in patients with poorly controlled type 2 diabetes: A randomized controlled splitmouth study. Medicina Oral Patologia Oral y Cirugia Bucal, 25(2), e154-e160. https://doi.org/10.4317/medoral.2 3061

Neuman, M. G., Nanau, R. M., OruñaSanchez, L., \& Coto, G. (2015). Hyaluronic acid and wound healing. Journal of Pharmacy and Pharmaceutical Sciences, 18(1), 53-60. https://doi.org/10.18433/j3k89d

Schneider, H. P., \& Landsman, A. (2019). Preclinical and Clinical Studies of Hyaluronic Acid in Wound Care: A Case Series and Literature Review. Wounds, 31(2), 41-48.

Vigetti, D., Karousou, E., Viola, M., Deleonibus, S., De Luca, G., \& Passi, A. (2014). Hyaluronan: Biosynthesis and signaling. Biochimica et Biophysica Acta General Subjects, 1840(8), 24522459.

https://doi.org/10.1016/j.bbagen.2 014.02.001 
Voigt, J., \& Driver, V. R. (2012). Hyaluronic acid and wound healing. Wound Repair and Regeneration, 20(3), 317-331. https://doi.org/10.1111/j.1524475X.2012.00777.x

Yıldırım, S., Özener, H. Ö., Doğan, B., \& Kuru, B. (2017). Effect of Topically-Applied Hyaluronic-
Acid on Pain and Palatal Epithelial Wound Healing: An Examiner-Blind, Randomized, Controlled Clinical Trial. Journal of Periodontology, 1-14. https://doi.org/10.1902/jop.2017.1 70105 